\title{
NOTES BY THE REV. J. E. HANAUER.
}

Sculptured Marble Slabs.-Just before leaving Jaffa (April 18th), in order to return to my work in Jerusalem, a German colonist, whose relatives own a steam-mill at Mejdel, near Askelon, came to inform me that a number of beautifully-sculptured marble slabs had recently been dug up at the latter place, but buried again by the natives"who found them. One of the slabs bore the picture of a man riding on the back of a large fish-I suppose a dolphin.

Terra-cotta Ooffins.-I have been informed by a young Englishman recently returned from a trip through the country, that quitelately (about three or four weeks ago) several large terra-cotta coffins, one of which my informant says he saw, were dug up near the Druse village of el Mansurah, at the foot of el Mahrakah, on Mount Carmel. With the exception of the one seen by the narrator, the others had all been broken up by the finders.

Rocl-hewn Vats.-On the afternoon of Friday, May 18th, Dr. Masterman, late your hon. local secretary at Damascus, and I were on our way to visit the settlement of Yemenite Jews on the western slope of the Mount of Offence, and south of the Moslem village of Silwan. We dismounted at Bîr Eyûb, and began to climb the steep ascent on foot, when, to our great surprise, on reaching the first rock terrace or ledge immediately east of Bîr Eyûb, and only a few yards (perhaps 30) from the old well itself, we found the remains of a great number of circular rock-hewn vats, about 27 inches in diameter at the top, and about 18 inches deep. I have this afternoon been down again, in order to examine these more closely, and at my. request $\mathrm{Mr}$. Charles. Hornstein, who accompanied Sir Charles Wilson to Petra last year, kindly consented to accompany me. We counted ahout30 of these vats. They are arranged in rows and at different levels, though near each other. Most of them are full of earth, but a few are empty. We also found traces of a well-cut staircase, leading past them up the hill. I had often before noticed this old. staircase, bat never thought it worth my while to examine it closely. This was the first time that I ever had occasion to cross the rock terrace, though, when working with 
Sir Charles Warren, over 30 years ago, I passed between it and Bîr Eyûb scores of times. Consequently, I had never before noticed the rock-hewn vats. Since finding them I have consulted every book that I could think of as. likely to throw light upon their being found here, but find no mention of them anywhere. Amongst other things, I have read the articles on En Rogel and the Fuller's Field, \&c., in the new edition of "Smith's Bible Dictionary," and, in spite of all the arguments against the tradition identifying Bîr Eyûb with En Rogel, I am sorely tempted to think that these newly-found remains decisively indicate the existence of fulling works at this particular spot in former times. The name En Rogel means (as I hardly need remind your readers) "the Spring of the Fuller." Just underneath the rock where these vats are there is a small opening into what Fellahîn at Bîr Eyûb told me was a large cave full of red earth. One of these peasants told Mr. Hornstein and me that this is the cave in which Sidna Eyûb ("our lord Job") lived when covered with leprosy. Our informant told us that he had often used the cave as a sheepfold. I had no time to explore it.?

Jertsalem, May 30th, 1900.

\section{INSCRIBED JAR-HANDLES OF PALESTINE.}

By Professor Clermont-Ganneat, LL.D.

I. - The statement made by Prof. Sayce (Quarterly Statement, January, 1900, p. 69) that in the collection of the Palestine Exploration Fund there is another jar-handle bearing the remains of a royal seal, is a very interesting fact in itself; and still more so, perhaps, because of certain archæological consequences which it may lead to, as I shall point out.

From the description given by Prof. Sayce, and the various labels which are stuck upon it, I have indeed recognised the fact

1 A further communication respecting these vats by Mr. Hanauer, with notes by Dr. Selah Merrill, has reached the offee of the Fund too late for publication in the present Quarterly statement. 